DOI: $10.19195 / 0137-1134.114 .31$

\author{
JAN GOLA \\ Uniwersytet Ekonomiczny we Wrocławiu \\ jan.gola@ue.wroc.pl
}

\title{
PREWENCJA W OBSZARZE AKTÓW KWALIFIKUJĄCYCH W DZIAŁALNOŚCI GOSPODARCZEJ
}

\begin{abstract}
Abstrakt: Artykuł dotyczy prewencyjnego charakteru aktów kwalifikujących w sferze publicznego prawa gospodarczego, które stanowią formę reglamentacji administracyjnej w gospodarce, a ich przedmiotem jest stwierdzenie pewnych stanów (prawnych i faktycznych) oraz ich ocena. W opracowaniu scharakteryzowano cechy tytułowych instrumentów jurydycznych oraz poddano analizie ich funkcję w obszarze nadzoru zapobiegawczego. Dokonano również podziału aktów kwalifikujących oraz zwrócono uwagę na ich znaczenie w działalności gospodarczej przedsiębiorców w społecznej gospodarce rynkowej, a także sformułowano wnioski dotyczące tej instytucji prawnej.
\end{abstract}

Słowa kluczowe: akty kwalifikujące, prewencja, instrumenty publicznego prawa gospodarczego, działalność gospodarcza, reglamentacja gospodarcza, policja gospodarcza

\section{WPROWADZENIE}

Na wstępie należy zaznaczyć, że akty kwalifikujące stanowią odrębną formę ograniczeń administracyjnych w gospodarce. Ich przedmiotem jest stwierdzenie pewnych stanów faktycznych i prawnych oraz ich ocena. Czynności te wykonywane są w ramach postępowania administracyjnego, w tym głównie postępowania wyjaśniającego, w którego efekcie wydawany jest akt kwalifikacyjny. Obszary stosunków gospodarczych, w których występują akty kwalifikacyjne, są bardzo zróżnicowane. Wskazuje się, że mogą to być dziedziny zainteresowania policji i reglamentacji gospodarczej ${ }^{1}$. Świadczy to o ich znaczeniu dla gospodarki i wpływie na czynności wykonywane przez przedsiębiorców. Co ważne, w społecznej gospodarce rynkowej tytułowa instytucja jurydyczna odgrywa znaczącą rolę w sferze funkcji państwa wobec gospodarki. Bez niej nie można byłoby bowiem w sposób prawidłowy chronić dóbr i stanów występujących na płaszczyznach funkcjonowania przedsiębiorców.

${ }^{1}$ K. Kiczka, Administracyjnoprawne środki ksztaltowania sytuacji prawnej przedsiębiorców, [w:] A. Borkowski et al., Administracyjne prawo gospodarcze, Wrocław 2009, s. 430. 


\section{AKTY KWALIFIKUJĄCE W DZIAŁALNOŚCI GOSPODARCZEJ}

Warto wskazać w tym miejscu na strukturę i podział aktów kwalifikujących. K. Kiczka zauważa, że takie określenia, jak „kwalifikujący”, „kwalifikowany”, „kwalifikacja prawna” i inne o podobnym znaczeniu, samodzielnie czy jako elementy pewnych wyrażeń, używane są w tekstach normatywnych. Autor zaznacza, iż o wiele częściej określenia te znajdują się jednak w orzecznictwie i literaturze publicznego prawa gospodarczego ${ }^{2}$. Wśród aktów kwalifikujących wyróżnia się akty osobowe (na przykład prawo jazdy, dyplom ukończenia studiów) oraz akty rzeczowe (dotyczące rzeczy w rozumieniu kodeksu cywilnego, przykładowo dowód rejestracyjny) ${ }^{3}$.

Przedstawiciele doktryny publicznego prawa gospodarczego podkreślają natomiast, że stanowiąc działania prawne administracji publicznej, akty kwalifikacyjne powstają w charakterystycznym dla siebie modelu stosowania prawa ${ }^{4}$. Ustalają one występowanie albo niewystępowanie pewnych elementów hipotezy normy prawnej. Rozstrzygnięcia administracji, jakie niosą omawiane czynności prawne, nie kształtują bezpośrednio konkretnych uprawnień i obowiązków jednostki, lecz odnoszą się do stwierdzenia pewnych cech osób i rzeczy ${ }^{5}$.

Akty kwalifikujące są indywidualnymi aktami administracyjnymi i mogą przybierać formę zarówno decyzji administracyjnej (w znaczeniu ogólnym, ale też w rozumieniu k.p.a.) ${ }^{6}$, jak i postanowienia. W postępowaniu administracyjnym odnoszącym się aktów kwalifikujących należy autorytatywnie określić, czy osoba fizyczna posiadała niezbędne uprawnienia do wykonywania danej działalności ${ }^{7}$. Istotnym elementem struktury prawnej aktu kwalifikującego jest wzorzec, według którego oceniane są właściwości osób i rzeczy ze względu na cel, jakiemu dana kwalifikacja ma służyć. Ma on zawsze charakter normatywny. Akty kwalifikujące, podobnie jak pozwolenia i koncesje, oprócz wywoływania skutków prawnych w publicznym prawie gospodarczym powodują także konsekwencje na innych obszarach prawa, na przykład w prawie podatkowym ${ }^{8}$.

Należy zaznaczyć, że konieczność posiadania stwierdzonych prawem kwalifikacji została stwierdzona przez ustawodawcę w przepisach ustawy z dnia 2 lipca 2004 roku o swobodzie działalności gospodarczej ${ }^{9}$. Zgodnie z tym aktem praw-

${ }^{2}$ K. Kiczka, Administracyjne akty kwalifikujące w działalności gospodarczej, Wrocław 2006, s. 47.

${ }^{3}$ K. Kiczka, Administracyjnoprawne środki ksztaltowania..., s. 431.

4 A. Chełmoński, Akty kwalifikacyjne administracji jako przedmiot badań, „Prawo” 266, 1999, s. 61 .

${ }^{5}$ K. Kiczka, Administracyjne akty kwalifikujace..., s. 76-77.

${ }^{6}$ Ustawa z dnia 14 czerwca 1960 r. - Kodeks postępowania administracyjnego (Dz.U. z 2018 r. poz. 149 z późn. zm.).

${ }^{7}$ K. Kiczka, Administracyjne akty kwalifikujace..., s. 69.

8 Ibidem.

9 Dz.U. z 2018 r. poz. 107 z późn. zm. (dalej: u.s.d.g.). 
nym, jeżeli przepisy szczególne nakładają obowiązek posiadania odpowiednich uprawnień zawodowych przy wykonywaniu określonego rodzaju działalności gospodarczej, przedsiębiorca obowiązany jest zapewnić, aby działalność ta była wykonywana bezpośrednio przez osobę legitymującą się posiadaniem takich uprawnień zawodowych ${ }^{10}$. Wskazuje się, że

sprawdzenie dokumentów poświadczających wymagane prawem kwalifikacje zawodowe osób zatrudnionych w ramach działalności gospodarczej odbywa się zarówno przed podjęciem działalności (np. w ramach udzielania koncesji i zezwoleń lub tworzenia przedsiębiorcy w określonej formie organizacyjno-prawnej), jak i w toku jej prowadzenia. Uprawnienia kontrolne w tym zakresie należą do licznego kręgu organów, poczynając od organów wydających koncesje i zezwolenia, przez organy specjalistyczne (np. inspekcję pracy) oraz organy samorządu zawodowego (np. aptekarskiego, lotniczego, lekarskiego) ${ }^{11}$.

Administracyjne akty kwalifikujące samodzielnie nie określają uprawnień i obowiązków przedsiębiorców, do których są kierowane. Wywołanie skutku prawnego przez akt kwalifikujący stanowi bowiem warunek sine qua non do odrębnego kreowania uprawnień i obowiązków przedsiębiorcy głównie w drodze systemu normatywnego, lecz także decyzyjnego ${ }^{12}$. Warto ponadto wskazać, że A. Chełmoński wyodrębnił dwa rodzaje wzorców w sferze administracyjnych aktów kwalifikujących - legalny oraz naukowo-techniczny. Pierwszy z nich to wzorzec określony wyraźnie i wyczerpująco w przepisach prawa. Podmiot, który dokonuje oceny, jest więc związany wprost przepisami określającymi właściwości osób lub rzeczy. Drugi typ to wzorzec, którego stosowanie wynika z norm odsyłających do ustaleń określonych gałęzi wiedzy. Tu podmiot dokonujący oceny odpowiednich właściwości według tego wzorca opiera się wyłącznie na swojej wiedzy fachowej i dokonując stwierdzeń oraz ocen, jest związany przede wszystkim własną rzetelnością zawodową ${ }^{13}$.

\section{PREWENCYJNY CHARAKTER AKTÓW KWALIFIKUJĄCYCH}

Nie ulega wątpliwości, że akty kwalifikujące pełnią funkcję prewencyjną w sferze podejmowania i wykonywania działalności gospodarczej. Obowiązek ich otrzymania może przyczynić się do zapobiegania wielu patologiom, takim jak korupcja czy pranie brudnych pieniędzy. Warto jednak zaznaczyć, że sama prewencja utożsamiana jest z szeroką grupą zachowań, które służą zabezpiecze-

\footnotetext{
10 Zob. art. 19 u.s.d.g.

11 C. Kosikowski, Ustawa o swobodzie działalności gospodarczej. Komentarz, Warszawa 2013.

12 K. Kiczka, Administracyjne akty kwalifikujące..., s. 72.

13 A. Chełmoński, op. cit., s. 61-62.
} 
niu i ochronie ${ }^{14}$. Służy ona bowiem zapobieganiu patologicznym zjawiskom oraz usuwaniu ich przyczyn. Składają się na to różnego rodzaju działania prowadzone przez instytucje i służby państwowe, organizacje społeczne oraz inne jednostki pełniące funkcję prewencyjną. Wskazuje się, że podmioty te mają za zadanie również uświadamianie, jakie zachowania (albo ich brak) są źródłem określonych zagrożeń. Trzeba dodatkowo podkreślić, że w oczywisty sposób powiązana jest z tym kontrola stanu przestrzegania przepisów prawa ${ }^{15}$.

Najistotniejsza z punktu widzenia omawianego tematu jest prewencja administracyjna. Jest ona szczególną cechą administracji, w której wykorzystuje się różne formy działania, to jest akty normatywne i administracyjne ${ }^{16}$. Trzeba zgodzić się ze stanowiskiem prezentowanym w doktrynie, że prewencja w prawie administracyjnym powinna być realizowana przez działania nadzorcze ${ }^{17}$, które przyczyniają się do zmniejszenia częstotliwości występowania zdarzeń uważanych za niepożądane i szkodliwe. Z całą pewnością można zatem stwierdzić, że prewencja w obszarze prawa administracyjnego dotyczy działalności zmierzającej do eliminowania określonego zjawiska lub jego skutków uznawanych za niepożądane przez podmiot podejmujący tę działalność ${ }^{18}$. Innymi słowy, prawidłowe funkcjonowanie aktów kwalifikujących przyczynia się do obniżenia kosztów społecznych oraz uzupełnia się z polityką kryminalną państwa. Efekty zaś prewencji administracyjnej powinny być widoczne także w przyszłości, w której następuje analiza przepisów prawa, również z punktu widzenia obiektywnych zasad ekonomii, a ocena użyteczności poszczególnych instytucji prawa antykorupcyjnego musi być formułowana na podstawie tych $\operatorname{zasad}^{19}$.

Akty kwalifikujące zostały umiejscowione w obszarach prawa gospodarczego publicznego. Sama zaś działalność policyjna i reglamentacyjna państwa zorientowana jest przecież prewencyjnie oraz powinna eliminować wszystkie zaistniałe naruszenia chronionych dóbr i stanów. Chcąc zapobiegać tego typu niebezpieczeństwom oraz je skutecznie usuwać, państwo przede wszystkim musi podjąć pewne działania prawodawcze, które polegają na ustanowieniu w aktach prawnych odpowiednich powszechnie obowiązujących nakazów i zakazów, o których już wspomniałem. Ich respektowanie przez społeczeństwo może być gwarancją nienaruszenia i zachowania pełnej integralności określonych dóbr objętych przez

14 Zob. J. Marecki, Zarys teorii kontroli gospodarczej, Warszawa 1989, s. 128, cyt. za: J. O1szewski, Nadzór nad koncentracją przedsiębiorców jako forma prewencyjnej ochrony konkurencji, Rzeszów 2004, s. 43.

15 Zob. J. Olszewski, op. cit., s. 43 n.

16 Zob. J. Lang, Współdziałanie administracji ze spoleczeństwem, Warszawa 1985, s. 47.

17 Zob. M. Szewczyk, Nadzór w materialnym prawie administracyjnym, Poznań 1995, s. 23.

18 Zob. J. Kwaśniewski, Profilaktyka społeczna: zwiazki ze stylami polityki społecznej oraz implikacje dla nauki, ,Prace Instytutu Profilaktyki Społecznej i Resocjalizacji UW” 3, 1979, cyt. za: J. Błachut, A. Gaberle, K. Krajewski, Kryminologia, Gdańsk 2006, s. 459.

19 Zob. A. Bator, Użycie normy prawnej w regulacji stosunków gospodarczych, Wrocław 2000, s. $61 \mathrm{n}$. 
państwo protekcją. Wprowadzenie wyszczególnionych nakazów i zakazów stwarza niezbędne warunki do obserwacji i oceny stanu dóbr prawem chronionych przez podmiot nadzorujących ${ }^{20}$. Zasadniczo wyróżnia się normy zakazujące pewnych działań, normy nakazujące pewne działania oraz pozwolenia jako działania uchylające pewien generalny zakaz (pewien nakaz) w stosunku do indywidualnie określonych podmiotów w konkretnych sytuacjach ${ }^{21}$.

Wspomniane nakazy i zakazy zaliczamy do władczych instrumentów generalnych administracji publicznej. Marek Szewczyk zaznaczył, że zakazy wydawane są najczęściej w odniesieniu do sytuacji, w których ustawodawca nie wprowadził prewencyjnych zakazów, natomiast ustanowił wymogi, których naruszenie może lub ma skutkować ograniczeniem wolności zachowań. Co ważne, autor stwierdza, że w takich przypadkach

pozostawieniu przez ustawodawcę ograniczonej wolności pewnych zachowań towarzyszy z zasady wprowadzenie prewencyjnego nakazu zawiadomienia, mającego ułatwić podmiotom nadzorującym ustalanie przypadków wymagających wydania zakazu ${ }^{22}$.

W tym miejscu należy wskazać na konkretne kategorie aktów kwalifikujących, które odgrywają rolę w sferze podejmowania i wykonywania działalności gospodarczej przez przedsiębiorcę lub osobę działającą na jego rzecz, oraz na ich zapobiegawczy charakter. Przykładem aktu kwalifikującego jest zaświadczenie o odbyciu szkolenia wskazane w przepisach reglamentujących obszar gier hazardowych. W ustawie z dnia 19 listopada 2009 roku o grach hazardowych ${ }^{23}$ normodawca stwierdza, że podmiot urządzający gry hazardowe, w tym podmiot urządzający gry hazardowe przez Internet, jest obowiązany zapewnić, aby osoby pełniące funkcję lub zajmujące stanowisko, z którym wiąże się obowiązek nadzorowania gier hazardowych — w szczególności dyrektorzy oddziałów, ośrodków gier oraz ich zastępcy, kierownicy i ich zastępcy, osoby nadzorujące gry telebingo, loterie fantowe, gry bingo fantowe, loterie promocyjne i loterie audioteksowe, inspektorzy w ośrodkach gier, kasjerzy stołu, osoby nadzorujące prowadzenie gier przez Internet albo obowiązek bezpośredniego prowadzenia gry hazardowej, w szczególności: krupierzy, obsługujący automaty do gier, urządzenia losujące lub urządzenia do gier, z wyłączeniem pracowników obsługi technicznej — przed rozpoczęciem wykonywania obowiązków na zajmowanym stanowisku lub pełnienia funkcji odbyły szkolenie z zakresu przepisów o grach hazardowych i regulaminów urządzanych gier w zakresie niezbędnym do wykonywania czynności związanych

20 Por. A. Radelbach, S. Wronkowska, Z. Ziembiński, Zarys teorii państwa i prawa, Warszawa 1992, s. 144.

21 A. Chełmoński, T. Kocowski, Reglamentacja działalności gospodarczej, [w:] A. Borkowski et al., op. cit., s. 56.

22 M. Szewczyk, op. cit., s. 121.

23 Dz.U. z 2018 r. poz. 165 z późn. zm. 
z nadzorowaniem i prowadzeniem gier ${ }^{24}$. Wskazane przez ustawodawcę szkolenie z zakresu przepisów o grach hazardowych i regulaminów urządzanych gier prowadzi podmiot urządzający gry hazardowe, w tym podmiot urządzający gry przez Internet, lub jednostka organizacyjna prowadząca działalność szkoleniową. Jest on zobligowany do wydania uczestnikowi szkolenia pisemnego zaświadczenia o odbyciu szkolenia. Podmiot ten obowiązany jest ponadto prowadzić w formie papierowej rejestr zaświadczeń pracowników, obejmujący dane pracownika, datę szkolenia, dane podmiotu wystawiającego zaświadczenie oraz numer zaświadczenia, do którego dołącza kopię zaświadczenia, poświadczoną za zgodność z oryginałem, którego oryginał znajduje się w aktach osobowych pracownika ${ }^{25}$.

Obowiązek uzyskania takiego aktu kwalifikującego niewątpliwie wpływa na ograniczenia wielu typów patologii w działalności gospodarczej i sprzyja pewności obrotu prawnego. Wskazane obowiązki i ograniczenia w uzyskaniu aktu kwalifikującego bez wątpienia przyczyniają się do zapewnienia prawidłowości w sferze podejmowania działalności gospodarczej przez przedsiębiorców w Polsce ${ }^{26}$.

Omawiając zagadnienia aktów kwalifikujących, warto jeszcze wspomnieć o aktach, które uprawniają do wykonywania zawodów prawniczych. Jako przykład takiego aktu kwalifikującego można wskazać decyzję o wpisie na listę adwokatów oraz legitymację adwokacką. Aby dana osoba mogła wykonywać zawód adwokata i otrzymać wspomniane dokumenty, musi między innymi zdać egzamin adwokacki. Zgodnie z art. 77a ustawy z dnia 26 maja 1982 roku — Prawo o adwokaturze ${ }^{27}$ to Minister Sprawiedliwości każdego roku powołuje, w drodze zarządzenia, zespół do przygotowania zestawu pytań testowych oraz zadań na egzamin adwokacki. W jego skład wchodzą czterej adwokaci delegowani przez Naczelną Radę Adwokacką oraz czterej przedstawiciele Ministra Sprawiedliwości, których wiedza i doświadczenie dają rękojmię prawidłowego przygotowania egzaminu adwokackiego. Pracami zespołu kieruje przewodniczący lub w wypadku jego nieobecności zastępca, powołani przez Ministra Sprawiedliwości spośród wymienionych osób.

Zdany egzamin adwokacki oraz nieskazitelny charakter stanowią zasadnicze przesłanki wydania decyzji o wpisie na listę adwokatów, co z kolei stanowi warunek wydania legitymacji adwokackiej. Wskazać należy, że powinno się dążyć do sytuacji, kiedy

wiedza i doświadczenie osób powołanych przez Ministra Sprawiedliwości do zespołu do przygotowania zadań na egzamin adwokacki są gwarancją wysokiego poziomu zadań przygotowywanych

24 Zob. wyrok Wojewódzkiego Sądu Administracyjnego w Olsztynie z dnia 15 grudnia 2015 r., II SA/O1 892/15 (Centralna Baza Orzeczeń Sądów Administracyjnych).

25 Zob. art. 24, 24b ustawy o grach hazardowych.

26 Zob. wyrok Wojewódzkiego Sądu Administracyjnego w Olsztynie z dnia 15 grudnia 2015 r., II SA/Ol 892/15.

27 Dz.U. z 2017 r. poz. 2368 z późn. zm. 
przez zespół i stanowią element pieczy nad wykonywaniem zawodu adwokata, o której mowa w art. 17 Konstytucji ${ }^{28}$, jako obowiązku samorządu zawodowego. Dbałość o wysoki poziom zawodowy adwokatów jest w interesie publicznym ${ }^{29}$.

Wspomniana regulacja prawna niezaprzeczalnie wpływa na zapobieganie patologiom w sferze podejmowania i wykonywania działalności gospodarczej przez adwokatów. Warto również nadmienić, że przed nowelizacją ustawy z 2009 roku egzamin przeprowadzany był tylko przez przedstawicieli samorządu zawodowego adwokatów, co sprzyjało licznym nadużyciom, korupcji oraz nepotyzmowi. Przestrzeganie zasad uczciwego prowadzenia działalności gospodarczej przez przedstawicieli zawodów prawniczych niewątpliwie odgrywa istotną rolę. Należy bowiem zaznaczyć, że człowiek, rozpoznając wartości, nieustannie musi wybierać spośród rzeczy, do których odnosi się w swoim działaniu, znajdując przedmioty o rozmaitym statusie aksjologicznym. W przebiegu życia ludzkiego zdarzają się momenty decydujące, gdy człowiek staje wobec wartości rozstrzygającej, którą jest właśnie uczciwość ${ }^{30}$. Przedstawiciele zawodów prawniczych muszą przestrzegać zasad etyki zawodowej, którą rozumiemy jako normy postulowane do przestrzegania i realizowania przez osoby wykonujące te zawody ${ }^{31}$. Jedynie osoba, która uzyska rzeczony akt kwalifikujący, może wykonywać działalność gospodarczą we wskazanym obszarze.

\section{PODSUMOWANIE}

Nie ulega wątpliwości, że akty kwalifikujące mają charakter prewencyjny. Stanowią formę reglamentacji administracyjnej w gospodarce, a ich przedmiotem jest stwierdzenie pewnych stanów (prawnych i faktycznych) oraz ich ocena. Biorąc pod uwagę ich oraz wielość funkcji, jakie pełnią w procesach wykonywania administracji publicznej, można stwierdzić, że ich znaczenie w regulacji prawnej współczesnych państw i struktur jest bezdyskusyjne. To ustawodawca zobowiązany jest bowiem do podjęcia środków niezbędnych do ustanowienia stosownych aktów kwalifikujących, które cechują się przejrzystością, a wydawane są na podstawie obiektywnych kryteriów. Ich prewencyjny charakter można potraktować jako swoiste zagadnienie systemowe, w którego obszar wchodzą środki zarówno prawne, jak i społeczne. Objęte są nim nie tylko podmioty stosujące działania profilaktyczne, lecz także adresaci ich działań.

28 Dz.U. z 2009 r. Nr 114, poz. 946.

29 J. Trela, [w:] P. Kruszyński, Prawo o adwokaturze. Komentarz, Warszawa 2016.

30 W. Chudy, Filozofia ktamstwa, Warszawa 2003, s. 377.

31 I. Bogucka, T. Pietrzykowski, Etyka w administracji publicznej, Warszawa 2010, s. 80. 
Funkcjonowanie sfery publicznej nie może być wolne od istnienia tytułowej instytucji jurydycznej, sama zaś złożoność funkcji i zadań współczesnej administracji gospodarczej wymaga rozbudowanego i przejrzystego systemu aktów kwalifikujących. Stworzenie i zapewnienie skuteczności takiego systemu należy uznać za jedną ze sfer współczesnego demokratycznego państwa prawa gwarantującą realizację zasad legalności działania administracji oraz zaufania obywateli do państwa. Akty kwalifikujące powinny bowiem służyć zwiększeniu kontroli społecznej nad wykonywaniem tej części władzy publicznej, a tym samym przyczyniać się do budowy społeczeństwa obywatelskiego, funkcjonującego, opierając się na mechanizmach demokratycznych, w warunkach społecznej gospodarki rynkowej.

\title{
PREVENTION IN THE SPHERE OF QUALIFYING ACTS IN COMMERCIAL ACTIVITY
}

\begin{abstract}
Summary
This article discusses the problem of a preventive character of qualifying acts in the sphere of public commercial law. The qualifying acts (decisions) form one of the elements of a broader sphere of regulation, i.e., administrative reglamentation in the market economy and their purpose is a determination of the existence of certain aspects (of legal or factual nature) and their subsequent quantification. The paper characterises the basic features of these juridical instruments as well as analyses their function in the sphere of preventive supervision. The entirety of qualifying acts was divided into subcategories, the significance of which with regard to commercial activity was also pointed out. In the ending, certain conclusions with regard to the said institution were also formulated.
\end{abstract}

Keywords: qualifying act, prevention, instruments of public commercial law, commercial activity, economic reglamentation, economic police

\section{BIBLIOGRAFIA}

Bator A., Użycie normy prawnej w regulacji stosunków gospodarczych, Wrocław 2000.

Błachut J., Gaberle A., Krajewski K., Kryminologia, Gdańsk 2006.

Bogucka I., Pietrzykowski T., Etyka w administracji publicznej, Warszawa 2010.

Chełmoński A., Akty kwalifikacyjne administracji jako przedmiot badań, „Prawo” 266, 1999.

Chełmoński A., Kocowski T., Reglamentacja działalności gospodarczej, [w:] A. Borkowski et al., Administracyjne prawo gospodarcze, Wrocław 2009.

Chudy W., Filozofia ktamstwa, Warszawa 2003.

Kiczka K., Administracyjne akty kwalifikujące w działalności gospodarczej, Wrocław 2006.

Kiczka K., Administracyjnoprawne środki kształtowania sytuacji prawnej przedsiębiorców, [w:]

A. Borkowski et al., Administracyjne prawo gospodarcze, Wrocław 2009.

Kosikowski C., Ustawa o swobodzie działalności gospodarczej. Komentarz, Warszawa 2013.

Kruszyński P., Prawo o adwokaturze. Komentarz, Warszawa 2016. 
Kwaśniewski J., Profilaktyka społeczna: zwiąki ze stylami polityki społecznej oraz implikacje dla nauki, „Prace Instytutu Profilaktyki Społecznej i Resocjalizacji UW” 3, 1979.

Lang J., Współdziałanie administracji ze społeczeństwem, Warszawa 1985.

Marecki J., Zarys teorii kontroli gospodarczej, Warszawa 1989.

Olszewski J., Nadzór nad koncentracją przedsiębiorców jako forma prewencyjnej ochrony konkurencji, Rzeszów 2004.

Radelbach A., Wronkowska S., Ziembiński Z., Zarys teorii państwa i prawa, Warszawa 1992.

Szewczyk M., Nadzór w materialnym prawie administracyjnym, Poznań 1995. 